The impact of entrepreneurship education, entrepreneurial self-efficacy and gender on entrepreneurial intentions of university students in the Visegrad countries

\author{
Haddoud, Mohamed Yacine
}

http://hdl.handle.net/10026.1/9867

10.1080/03075079.2017.1365359

Studies in Higher Education

Informa UK Limited

All content in PEARL is protected by copyright law. Author manuscripts are made available in accordance with publisher policies. Please cite only the published version using the details provided on the item record or document. In the absence of an open licence (e.g. Creative Commons), permissions for further reuse of content should be sought from the publisher or author. 


\section{The impact of entrepreneurship education, entrepreneurial self-efficacy and gender on entrepreneurial intentions of university students in the Visegrad countries}

Witold Nowiński , Mohamed Yacine Haddoud, Drahoslav Lančarič, Dana Egerová \& Csilla Czeglédi

\section{Introduction}

Both researchers and public policy makers widely recognize that entrepreneurship is an important driver of economic growth (Fayolle and Gailly 2008; Stamboulis and Barlas 2014; Van Praag and Verslot 2007). As a result, policies and educational programs aimed at fostering entrepreneurial activity have emerged. While public policy generally suggests that entrepreneurship education contributes to entrepreneurship (European Commission 2006) research results are not altogether conclusive. Although the majority of studies confirm a positive linkage between entrepreneurship education and entrepreneurial intentions (Bae et al. 2014; Martin McNally and Kay 2013; Rauch and Hulsink 2015; Sanchez 2013; Souitaris, Zerbinati and Al-Laham 2007) there are also studies which show opposite results (Oosterbeek, van Praag and Ijsselstein 2010). Additionally, while the topic has been studied widely in the western literature, it is much less researched in the context of Central and Eastern European (CEE) countries. Therefore, this study aims to fill this gap by addressing the question of whether entrepreneurship education in the Visegrad countries increases the entrepreneurial intentions of students in Higher Education Institutions (HEIs). In this way, the study will contribute to the debate on the impact of entrepreneurship education on the entrepreneurial intentions of university students. The other contribution of the paper stems from a gender comparison, allowing an enhanced understanding of the interplay between education, intentions and gender. This is an important issue as we know that women are 
underrepresented among entrepreneurs in the EU, where they only account for $31 \%$ of all entrepreneurs. Previous studies indicated that women, including female students, display lower entrepreneurial intentions than men (Kelley et al. 2012; Kurczewska and Białek 2014). However, research provides mixed evidence in respect to the benefits which female students gain from entrepreneurship education, with some studies indicating that women benefit more than men (Bae et al. 2014) while others suggest otherwise (Oosterbeek, van Praag, and Ijsselstein 2010; Westhead and Solesvik 2016). This contradiction might be explained by involving additional variables, such as entrepreneurial self-efficacy, which are likely to affect the link between education, gender and entrepreneurial intentions (Thébaud 2010).

Visegrad countries: The Czech Republic, Hungary, Poland and Slovakia share a similar history of a communist regime imposed by the Soviet union after World War II followed by transition to western style democracy from around 1990. At the beginning of the 1990s, all four countries moved from a command economy to a free market economy. Nowadays entrepreneurship is regarded as an important driver of economic growth in the region. Public administration in the Visegrad countries undertakes various steps, often with the help of European Union funds, to boost entrepreneurship activity, including that of recent graduates Egerová et al. (2016). Entrepreneurship education could be regarded as part of a policy mix aimed to increase this activity. In order to fully understand its role, however, one needs to understand whether, and possibly to what extent, this education contributes to entrepreneurial intentions.

This issue is important for several reasons. First, there has been an ongoing debate concerning reforms in university education aimed at increasing its positive impact on human capital, particularly on the employability skills of the graduates (Cranmer 2007; Fallows and Steven 2000; Sin and Neave 2016). Second, entrepreneurship education may not only serve as a driver for entrepreneurial activity of university graduates but also improve their chances on 
the job market (European Commission 2012). However, the actual situation in this respect in the Visegrad countries is unknown. We neither know if entrepreneurship education in these countries contributes to entrepreneurial intentions nor whether its influence is equal for different student groups, in particular for different genders.

\section{Conceptual Framework}

As Pittaway and Cope (2007) argue, the link between entrepreneurship education and entrepreneurial intentions is generally under researched. This is particularly true in the Central and Eastern European context. We found only two papers on the relationship between entrepreneurship education and entrepreneurial intentions that focused strictly on one of the four countries considered in this study. Gaweł and Pietrzykowski (2013) compared the entrepreneurial intentions of Polish business students participating in a course on international entrepreneurship. They found that their entrepreneurial intentions subsequently increased, although their paper lacked tests of statistical significance. Similarly, Packham et al. (2010) found that enterprise education had a positive influence on the entrepreneurial attitude of Polish students. The four Visegrad countries were included in a recent paper by Van der Zwan, Zuurhout, and Hessels (2013) who conducted a multi country study which found a positive relationship between entrepreneurship education and self-employment. However, due to its cross-national nature it is not possible to draw solid conclusions about the strength of this relationship in particular countries. Nevertheless, it is possible to make some indirect inferences from other studies. Recent meta-analyses concerning the relationship between entrepreneurship education and entrepreneurial intentions (Bae et al. 2014; Martin McNally and Kay 2013) overall indicated that there is a positive relationship between entrepreneurship education and entrepreneurial intentions. Simultaneously, Walter and Block (2016) found that the strength of this relationship is stronger in countries where the institutional 
environment is relatively less entrepreneurship friendly. Visegrad countries can still be classified as countries with a relatively less friendly institutional environment towards entrepreneurship than Western market economies. Therefore, relying on the scarce empirical evidence from the Visegrad countries as well as by drawing inferences from cross-national studies we pose the following hypothesis:

Hypothesis 1: Entrepreneurship education positively affects the Visegrad countries students' entrepreneurial intentions

\section{EE and EI: the Indirect Influence through ESE}

According to Bandura's social learning theory (1977) there is a link between selfperceptions of personal skills in performing certain tasks and career decisions. These perceptions are often referred to as self-efficacy. In the context of entrepreneurship, Boyd and Voizikis (1994) linked entrepreneurial self-efficacy (ESE) with entrepreneurial intentions and actions while Krueger and Brazeal (1994) regarded it as a prerequisite of an entrepreneur. Both leading theories which explain entrepreneurial intentions, Ajzen's Theory of Planned Behavior and Shapero-Krueger's Entrepreneurial Event Model, treat perceptions of entrepreneurial self-efficacy as an important contributor to entrepreneurial intentions (Krueger, Reilly, and Carsrud 2000). These links have been empirically verified by various scholars (Chen, Greene and Crick 2008; Krueger, Reilly and Carsrud 2000; Luthje and Franke 2003). A positive relationship between ESE and entrepreneurial intentions has also been found in the Polish context (Kurczewska and Białek 2014). Concluding, we suggest that:

Hypothesis 2: Entrepreneurial self-efficacy positively affects the Visegrad countries students' entrepreneurial intentions. 
In his Social Cognitive Theory Bandura (1977) mentions that one's expectations concerning self-efficacy are developed from four sources of information: performance accomplishments, vicarious experience, verbal persuasion and physiological states. Zhao, Seibert and Hills (2005) argue that entrepreneurship education could provide all four or at least some of these sources. During entrepreneurship courses, students can perform practical projects and thus increase their self-efficacy through tangible accomplishments. They can meet, watch or discuss stories of successful entrepreneurs which are sources of vicarious learning. Finally, they can be persuaded that an entrepreneurial career is a reachable goal and develop positive emotions, for example, due to group interactions. Therefore, we propose the following hypothesis.

Hypothesis 3: Entrepreneurial education positively affects the Visegrad countries students' entrepreneurial self-efficacy.

If $\mathrm{H} 2$ and $\mathrm{H} 3$ were positively verified we could claim a mediation effect of ESE between entrepreneurship education and entrepreneurial intentions. In fact, the intervening role of ESE in the link entrepreneurship education-entrepreneurial intention has been acknowledged and tested in several previous works (Maresch et al. 2016, Zhao, Seibert and Hills 2005). Krueger and Brazeal (1994) claim that entrepreneurship education enhances students' knowledge, increases their confidence, and boosts their self-efficacy, which would in turn, enhance their perception of the feasibility of entrepreneurship and hence foster their intention. Similarly, Zhao, Seibert and Hills (2005) establish that ESE offers a solid theoretical explanation for the relationship between formal learning and entrepreneurial intention. Entrepreneurship education increases students' confidence to become an entrepreneur through mechanisms 
known to affect self-efficacy beliefs. In this vein, our study aims at formally testing the mediating influence of ESE in the CEE context.

\section{EE and EI: the Contextual Influence}

Determinants of entrepreneurial intentions are often regarded as context specific (Bae et al. 2014, Lüthje and Franke 2003). Therefore, cross-country studies which aim to explain entrepreneurial intentions should refer to the specific national context which might affect the level of entrepreneurial intentions. Three such contextual variables, namely cultural characteristics, historical background, and institutional framework will be briefly discussed.

Bae et al. (2014) found that cultural differences might affect the linkage between entrepreneurship education and entrepreneurial intentions in such a way that it is positively moderated by high in-group collectivism, low gender egalitarianism and low uncertainty avoidance. In the present study a similar reasoning is applied. It could be argued that the cultural differences across the four countries may alter the influence of entrepreneurship education on entrepreneurial intention. Of the four countries studied Slovakia is relatively the most collectivist, scores highest for masculinity and lowest for uncertainty avoidance (Table 1) which suggests that entrepreneurship education might have the greatest impact on entrepreneurial intentions in this country.

Table 1 to be inserted around here

More importantly, the analysed countries display certain differences in respect to education and in particular to the role of entrepreneurship education in the curricula. Poland is the only country to have entrepreneurship classes at a high-school level. As far as university education is concerned, prior comparative research (Egerová et al. 2016) shows that the extent to which entrepreneurship education is covered in learning outcomes differs between the four Visegrad 
countries. The same study documents differences concerning the inclusion of courses directly aimed at entrepreneurship in the study programs. These differences might not only lead to different levels of exposure to entrepreneurship education but could also affect the overall effectiveness of educational systems in respect to entrepreneurship education.

Concluding, there are certain contextual differences between the studied countries which may evoke differences in the strength of the relationships between entrepreneurship education, intentions and self-efficacy. Therefore, in order to verify whether, and possibly to what extent, the factors described above affect the relationship between entrepreneurship education with entrepreneurial intentions and entrepreneurial self-efficacy the following hypothesis will be tested:

Hypothesis 4: The impact of entrepreneurship education on the Visegrad countries students' (a) entrepreneurial intentions, and (b) entrepreneurial self-efficacy is likely to differ across the four countries.

\section{EE and EI: the Gender Influence}

Women make up a substantial part of the university student population in Visegrad countries, ranging between 55 and $60 \%$ of total tertiary students (Eurostat 2015). Previous studies have shown, however, that women not only display lower entrepreneurial intentions than men (Santos, Roomi and Liñán 2016; Wilson, Kickul and Marlino 2007) but also lower entrepreneurial self-efficacy (Dempsey and Jennings 2014; Wilson, Kickul, and Marlino 2007). It seems therefore highly relevant to analyze separately for men and for women how entrepreneurship education affects their entrepreneurial intentions.

Prior research provides an ambiguous picture in respect to the impact of gender on the link between entrepreneurship education and entrepreneurial intentions. While some studies show that the impact of entrepreneurship education on entrepreneurial intentions is more positive 
(or less negative) for men than for women (Oosterbeek, van Praag and Ijsselstein 2010; Westhead and Solesvik 2016) other studies do not report any significant difference across the two groups (Bae et al. 2014). The picture becomes still more complex when the impact of self-efficacy is taken into account. Thébaud (2010) shows that women need a higher level of education to assess themselves as capable to perform entrepreneurship related tasks. Because of cultural beliefs about gender roles, women perceive themselves as less competent in tasks normally regarded as male, such as entrepreneurship. For this reason they need a higher level of education to perceive themselves as sufficiently competent and ready to take up an entrepreneurial career. In a similar vein, Wilson, Kickul and Marlino (2007) show that entrepreneurship education has positive effects on entrepreneurial self-efficacy and these are stronger for women than for men. This gender specific effect could be related to students' learning experience as it has been found that female students perceive greater benefits from entrepreneurial education than men (Packham et al. 2010). However, other research has indicated a contradictory effect of gender on the EE-ESE relationship (Shinnar, Hsu and Powell 2014). In summary, despite the lack of consistency with respect to the role of gender noted in previous studies, we propose the following hypothesis:

Hypothesis 5: The influence of Entrepreneurship Education on the Visegrad countries students' (a) Entrepreneurial Self-Efficacy and (b) Entrepreneurial Intentions differs between male and female students

Our conceptual framework is summarised in Figure 1. This model extends previous models in three ways. First, it simultaneously explores both direct and indirect influences of entrepreneurship education on students' entrepreneurial intention. Second, it captures ESE through a multi-dimensional construct which would offer greater insight on the mediating role 
of ESE. Third, it tests the hypothesised relationships in the four different Visegrad countries and compares the findings across male and female samples.

Figure 1 to be inserted around here

\section{Method}

Data for this study was collected from the four Visegrad countries: the Czech Republic, Hungary Poland and Slovakia during 2015. The research took place in multiple universities/campuses in each country: 5 in Poland, 3 in Slovakia, 2 in the Czech Republic and 2 in Hungary. The study adopted a non-probability convenience sampling procedure. Notwithstanding its generalisability issue, non-probability sampling is prevalent in entrepreneurship-related studies (Ahl 2006; Coviello and Jones 2004). Given the challenging nature of the entrepreneurship discipline (Jensen and Luthans, 2006), the use of convenience sampling (a form of non-probability methods) has been reported in several entrepreneurship studies (e.g. Louw et al. 2003; Thompson 2009; Wilson, Kickul and Marlino 2007; Wilson et al. 2009; Wu 2007) and particularly those involving multiple countries (Davey et al., 2011; Kautonen, Gelderen and Fink 2015; Kemelgor, 2002; Mitchelmore and Rowley 2013). In this vein, Coviello and Jones (2004) argue that despite the well-acknowledged generalisability issues, non-probability sampling can result in good quality data when samples are characterised with high response rates and participation levels. It is also argued that using convenience sampling allows the researcher to ensure the appropriateness of participants (Carland et al. 2001). This being said, to reduce the generalisability issue, efforts were undertaken to achieve a sufficient sample size to compensate for its non-random character. In 
addition, multiple countries were included and tests were applied to ensure similar variations across the four countries (details to follow).

The survey was administered by means of a questionnaire, which was distributed among students in either paper or electronic forms. Paper questionnaires were administered by the team participating in the project and affiliated researchers who were instructed in respect to data collection. In all countries questionnaires were administered and collected during classes. Although participation was voluntary the large majority of the invited students decided to participate. The questionnaire surveys in electronic form were distributed by means of university extranet and e-learning platforms to students in Poland, the Czech Republic and Hungary. Their share in the total sample was $44 \%$ in Poland, $68 \%$. in the Czech Republic and $100 \%$ in Hungary. In order to verify whether the manner of administering the survey could have affected its results t-tests were run for all items included in the model. For the vast majority of items (27 out of 28) no significant differences were detected. Questionnaires were mostly addressed to final year students to increase the likelihood of their having been exposed to entrepreneurship education at tertiary level. Overall, the sample included both business and non-business students. The majority of students were female, in line with the gender structure of university students in the Visegrad countries. From a total sample of 1223, we deleted 201 responses from students who had been self-employed, as in such cases it is difficult to assess the meaning of entrepreneurial intentions. As a result, the total usable sample size was 1022 , of which 253 were obtained in Hungary, 421 in Poland, 178 in the Czech Republic and 170 in Slovakia.

Measures applied in the study mostly followed previous studies. Entrepreneurial intentions were measured using questions derived from Liñán and Chen (2009), whose study showed the high reliability of this construct (Cronbach alpha of .943). Following Liñán and Chen (2009) students were asked to indicate on a five point scale their level of agreement with six 
statements, such as for example: " My professional goal is to become an entrepreneur " and " I have very seriously thought of starting a firm ". Entrepreneurial self-efficacy was measured following McGee et al. (2009) as a multidimensional construct which consists of five subconstructs: searching, planning, marshalling, implementing (people) and implementing (finance). This construct was measured by asking students to assess on a 5 point scale how much confidence they had in their ability to carry out 19 different actions typical for entrepreneurial activity. Examples of these items include: "Identify the need for a new product or service", " Estimate the amount of start-up funds and working capital necessary to start my business ", "Network - i.e., make contact with and exchange information with others" and "Train employees". McGee et al.'s (2009) study showed the ESE sub-constructs to be both highly reliable (all Cronbach alphas exceeding .8) and to possess adequate convergent and discriminant validity. The described constructs were measured as reflective. Entrepreneurial education was measured using one question which asked the respondents to assess on a 1-5 scale how much time during their university studies was devoted to studying entrepreneurship (where 1 denoted no or very little time and 5 denoted a lot of time ). Gender was a dummy variable, where men were coded as 1 and women as 0 .

The model was assessed through Partial Least Square Structural Equation Modeling PLS SEM, using Smart PLS (Ringle, Wende, and Becker 2015). The reason for adopting this approach, rather than covariance based SEM was that it allowed us to explore complex relationships, and ultimately to assess to what extent entrepreneurship education and student gender can predict entrepreneurship intentions. In such a case PLS SEM would seem to be the natural choice (Hair et al. 2016; Lowry and Gaskin 2014). PLS SEM methodology first requires an assessment of the measurement model which links latent constructs with their indicators and then an assessment of the structural model which links latent variables. The two models are assessed in the following section 


\section{Results and Discussion}

\section{Measurement Model}

The model includes two single item constructs (entrepreneurship education and gender) and several multi-item latent constructs. These are entrepreneurial intentions and entrepreneurial self-efficacy, which consists of five latent sub-constructs. Since all variables were reflective, their reliability was measured by Cronbach's Alpha and Composite Reliability while convergent validity was measured by Average Variance Extracted. As shown in Table 2, all measures performed well.

Table 2 to be inserted around here

According to the Fornell and Larcker criterion (1981) discriminant validity is established when square roots of AVE are greater than the correlations with the remaining constructs. As table 3 indicates, this criterion has been fulfilled (values of AVE square roots are on the diagonal).

Table 3 to be inserted around here

Additionally, we ascertained that common method variance did not affect the outcome by conducting Harman's single factor test (Podsakoff et al. 2003), finding that the single factor was below the expected threshold level of 50\% (Lings et al. 2014). Moreover, no multicollinearity problems were found as all VIFs were below 5, with the highest at 3.01 (see table 2). 


\section{The Structural Model}

Following validation of the measurement model, the structural model was assessed. Figure 2 presents path coefficients (hypotheses $\mathrm{H} 1-\mathrm{H} 5$ ), statistical significance and $\mathrm{R}^{2}$ for the structural model.

Figure 2 to be inserted around here

\section{Entrepreneurship Education and Entrepreneurial Intentions.}

The results indicate that Entrepreneurship education contributes to entrepreneurial intentions but it does so indirectly via improving students' ESE. The direct path between EE and EIs is non-significant (Figure 2) which would suggest that we have to reject H1. Looking at path coefficients of individual countries (Table 4) we find, however, that in one country, Poland, this path is significant, even if the effect is not strong. As for the indirect influence, it can be seen from Figure 2 that the impact of EE on EIs is fully mediated by three dimensions of ESE: marshalling, searching and planning $\left(\beta_{\text {indirect effect }}=0.128 ; p\right.$ indirect effect $\left.\leq 0.01\right)$. The explained variance for the full model $\left(\mathrm{R}^{2}\right)$ is 0.236 . Although EE also contributes to ESE related to managing people and finances these two ESEs do not contribute to EIs. These results let us demonstrate that we obtain partial support for $\mathrm{H} 2$, which stated that ESE positively affects the entrepreneurial intentions of Visegrad students and full support for $\mathrm{H} 3$ concerning the positive impact of entrepreneurial education on their ESE. Our findings clearly indicate that the contributing effect of entrepreneurial education on entrepreneurial intentions of Visegrad students will be maximised when education focuses particularly on topics related to searching for business ideas and gathering resources. Other topics, such as business planning, HR management and financial management, while undoubtedly important for other 
aspects of the business creation process, do not contribute as much to students' entrepreneurial intentions.

\section{Entrepreneurship Education and Entrepreneurial Intentions: A Cross-Country Analysis.}

Due to the acknowledged differences between the four countries, our fourth hypothesis was to verify whether the relationships between entrepreneurship education and entrepreneurial selfefficacy and entrepreneurial intentions would differ across the four samples.

In order to check for differences across the four countries under investigation, a multigroup analysis was applied. The premise behind conducting such an analysis is to assess whether the differences (if any) across the four contexts are significant. To do so, we applied a non-parametric PLS Multi-Group Analysis (known as PLS-MGA) established by Henseler et al. (2009). However, to obtain meaningful results, it is first necessary to check for any measurement variance across the four countries (Hair et al. 2016). Confirming measurement invariance was conducted following Henseler, Ringle and Sarstedt's (2016) MICOM approach. According to the authors, a PLS-MGA can only be conducted when at least configural invariance and compositional invariance are established. With respect to the former, we made sure that the data treatment, the measurement and structural models and the algorithm settings were all equal across the four countries. Thus, we are able to confirm the existence of configural invariance. For the latter, we conducted a permutation procedure with a minimum of 1000 permutations and 5\% significance level for each combination of countries. Following this, a comparison was made of the original score correlations $c$ against the empirical distribution of the score correlations obtained through the permutation process $(c u)$, to see whether c exceeds the $5 \%$ quantile of $c u$. If this is the case, then a compositional invariance can be confirmed (Schlägel and Sarstedt 2016). Table 5 mostly confirms these 
assumptions. Having established both invariances, we can claim a partial measurement invariance which allows us to proceed with the PLS-MGA.

The following table (Table 6) reports the differences in paths across the four countries. pvalues below 0.05 or above 0.95 suggest significant differences across the two groups. To illustrate these differences further, Table 4 provides the path coefficients and $p$ values of each country separately. Regarding the direct influence of entrepreneurship education on entrepreneurial intentions (see table 5), Poland is the only country in which such a link is positive and significant. This implies that the effect of entrepreneurship education on entrepreneurial intentions is not uniform across the four countries and hence hypothesis H4a holds. Interestingly the observed difference between Poland and Slovakia runs counter to the suggestions of Bae et al. (2014) concerning the impact of culture-related contextual moderators. In line with these suggestions the relationship between entrepreneurship education and intentions should be stronger for Slovakia, which in comparison to Poland scores higher in terms of collectivism and masculinity and lower in terms of uncertainty avoidance. Meanwhile, in the case of Slovakia the path, although insignificant, is negative and for Poland it is significant and positive. Therefore, we could interpret the observed differences by bearing in mind the characteristics of entrepreneurship education systems in Visegrad countries. One needs to note, however, that previous studies comparing entrepreneurship education systems in universities do not provide fully consistent results. Thus, while on the one hand Poland is relatively the most advanced out of the four studied countries in introducing entrepreneurship content into National Qualifications Frameworks at university, on the other hand analysis of study programs shows that Slovakia exceeds Poland in the share of study programs which include courses directly aimed at entrepreneurship content (Egerová et al. 2016). Therefore, a more likely explanation of the observed differences between Poland and Slovakia might be related to the fact that Poland is the only 
one of the four countries which has introduced entrepreneurship education at a high-school level. Such an early introduction of entrepreneurship education could strengthen the effectiveness of entrepreneurship education at the university level. A recent longitudinal study by Elert, Andersson, and Wennberg (2015), conducted in Sweden, found that individuals who undertook a junior entrepreneurship program in high school were more likely to engage in a new venture and generate higher incomes. The authors argued that such programs provide pupils with the opportunity to develop entrepreneurial skills at an early stage and to experience the whole lifecycle of a company using a "learning-by-doing" approach. Similarly, in the Netherlands, Huber, Sloof, and van Praag (2014) reported that entrepreneurial skills are more easily developed earlier in life. Their experimental study showed that early educational programs play a major role in enhancing pupils' non-cognitive entrepreneurial skills when compared to the control group.

Tables 4,5 and 6 to be inserted around here

As for the indirect influence of entrepreneurship education on entrepreneurial ESEs, the following differences were noted. First, in terms of ESE implementing finance, entrepreneurship education in Slovakia, Poland and Hungary had a high equal influence on this ESE. In contrast, entrepreneurship education in the Czech Republic had no influence on implementing finance ESE (significant differences between Czech Republic and the remaining countries). Second, in terms of ESE implementing people, entrepreneurship education had a high equal influence on this ESE in Hungary and the Czech Republic; these were followed by Poland where the influence of entrepreneurship education was significantly lower than in Hungary yet still close to the Czech Republic. In contrast, entrepreneurship 
education in Slovakia had no influence on ESE implementing people. Third, in terms of ESE planning, entrepreneurship education in Hungary and Poland had the highest equal influence on this ESE, followed by Slovakia where entrepreneurship education had an influence that was significantly lower than in Hungary yet still close to Poland. In contrast, entrepreneurship education in the Czech Republic seems to have no influence on ESE planning. Finally, the influence of entrepreneurship education on both marshalling and searching ESEs was equally high across the four countries.

As for the influence of ESEs on entrepreneurial intentions, the following differences were noted. First, Hungary seems to be the only country where ESE implementing finance has any significance for entrepreneurial intention. Second, Slovakia seems to be the only country where ESE implementing people matters, however, this has a negative influence on entrepreneurial intention. Third, Slovakia and Poland appear to be the only countries in which ESE marshalling has an equally high positive influence on entrepreneurial intentions. Fourth, Slovakia and the Czech Republic are, this time, the only countries for which ESE planning has a significant and positive influence on entrepreneurial intentions (equal strength). Finally, Searching ESE has an equally positive and high influence across the four countries.

In summary, Hungary would appear to be the country in which entrepreneurship education was generally the most efficient in increasing ESEs, particularly in terms of implementing finance, implementing people and planning ESEs. Subsequently, Slovakia, the Czech Republic and Poland seem to follow with varying levels of efficiency in different ESEs . However, in terms of Marshalling and Searching ESEs, all four countries did equally well in increasing such traits. Hence, we can accept $\mathrm{H} 4 \mathrm{~b}$ and confirm that entrepreneurship education has different impacts in countries with different cultures and different education systems, as argued by several scholars (Mwasalwiba 2010; Packham et al. 2010). Preston and Green (2003) posit that differences between countries and their systems are likely to affect the 
impact of educational intervention, while Packham et al. (2010) provide evidence that cultural norms and industrial heritage can affect the relationship between entrepreneurship education and intention.

\section{Entrepreneurship Education and Entrepreneurial Intentions: The role of Gender}

Although we did not include any hypotheses concerning differences between men and women in terms of their entrepreneurial intentions and entrepreneurial self-efficacy, presenting information on these differences will provide a background for further analysis in which gender impact on the relationship between entrepreneurship education and entrepreneurial self-efficacy can be studied. By means of t-tests it was determined that across the studied countries men display higher levels of entrepreneurial intentions as well as higher entrepreneurial self-efficacy in those dimensions which were found to be key predictors of entrepreneurial intentions (ESE searching, planning and marshalling). This confirms previous evidence suggesting that entrepreneurship is considered as a typical masculine career (Gupta

et al. 2009; Shinnar, Hsu and Powell 2014), where women would consider the pay-offs of entrepreneurship to be less appealing (Baumol 1990). Moreover, female entrepreneurs perceive a conflict between their traditional female gender roles and the nature of the entrepreneurship identity (Díaz-García and Welter 2011).

Following the country comparison it was deemed relevant to conduct a gender comparison. Measurement invariance was tested and established following the same procedure as in the comparison between countries (details available upon request). Table 7 shows the differences across the two groups, while table 4 shows the path coefficients and $p$ values for both genders separately. From both tables, it can be argued that although the direct impact of entrepreneurship education on entrepreneurial intentions did not display any significant differences for men and women, the influence of entrepreneurship education on planning and marshalling ESEs was higher amongst females than males. The remaining paths were found 
to be similar across the two groups. It could be concluded that entrepreneurship education is significantly more efficient in increasing marshalling and planning ESEs amongst females, when compared with males. Hence, we can confirm H5. This finding is consistent with the research of Packham et al. (2010) who found that entrepreneurship courses increased perceptions of entrepreneurial knowledge among Polish female students more than among male students. However, contrary to Packham et al. (2010) we found no significant differences in the impact of ESE on the entrepreneurial intentions of female and male students, which effectively leads us to conclude that the indirect impact of entrepreneurship education on entrepreneurial intentions is stronger for women than for men.

Our findings show that entrepreneurship education contributes in particular to those dimensions of entrepreneurial self-efficacy for which women score lower than men and which are important mediators between education and intentions. Our research in this respect is in line with Wilson, Kickul, and Marlino's study (2007) while inconsistent with Shinnar, Hsu and Powell (2014). Nevertheless, our study not only replicates analyses of the gender moderated relationship between entrepreneurship education and entrepreneurial self-efficacy in a Central European context but extends them by applying a multidimensional approach to entrepreneurial self-efficacy and thus identifying which dimensions of ESE are crucial. We thus provide indirect support for the claims of Drnovš̉ek, Wincent and Cardon (2010) who argued that the inconsistent findings on the influence of entrepreneurship education on female students' ESE are due to the multifaceted nature of ESE that is often ignored by researchers. In short, our study shows that entrepreneurship education is particularly important for women. While Thébaud (2010) demonstrated that higher education generally improves womens' selfperception of their entrepreneurial competences, hence contributing to their entrepreneurial intentions, we show that entrepreneurship education contributes to specific dimensions of women's entrepreneurial self-efficacy. Hence, our result prove that entrepreneurship 
education can at least partly offset the negative impact of cultural stereotypes which hold that women are less fit for entrepreneurial careers.

Taking a more critical stance, other research on entrepreneurship education in Central and Eastern Europe (Egerová et al. 2016) has shown that entrepreneurship courses tend to be taught in traditional ways, often relying on lectures as the main, if not the only teaching method. Earlier research indicates that men are more interested in education when they expect it to increase their qualifications while women are interested in learning for learning's sake (Severiens and ten Dam 1994), and additionally that male students may prefer multiple modes of teaching more than female students (Wehrwein, Lujan and DiCarlo 2007). This is an alternative explanation for the more positive effect of entrepreneurship education in its current, traditional form among women in comparison with men. This might, however, imply that increasing the practical dimension of entrepreneurship education while improving overall education experience and its impact on ESE and EIs might be more effective for men than for women. This could also offer another explanation of why studies which examine gender as a moderator of the relationship between education and EIs provide divergent results (Shinnar, Hsu, and Powell 2014, Wilson, Kickul and Marlino 2007) as this may stem from crosscountry and even intra-country differences in respect to teaching methods and their potentially different effects on men and women.

Table 7 to be inserted around here

\section{Implications for Practice}

This study offers practical implications for public policy. First, it suggests that governments of Central European countries can support entrepreneurship of university graduates by creating an institutional framework which facilitates access of university students to 
entrepreneurship education. Although many students have such access, previous research (Egerová et al. 2016) indicates that institutional solutions may limit entrepreneurship education to certain fields of study. Secondly, this support may be even more effective if students enter universities with some basic knowledge of entrepreneurship which they could obtain at earlier stages of education. The only country to have offered entrepreneurship education at secondary level was Poland, which was also the only country to show any direct positive effects of entrepreneurship education on intentions. It can be expected that by embracing entrepreneurship education at such an early stage the other Visegrad countries would further increase their graduates' interest in entrepreneurial careers. Thirdly, in order to increase entrepreneurial intentions educators should particularly focus on three dimensions of entrepreneurial self-efficacy: searching, planning and marshalling. One needs to note that this does not mean that the other dimensions of entrepreneurial self-efficacy are irrelevant for entrepreneurial careers but rather that they may not be as crucial in the development of entrepreneurial intentions. This could mean that early entrepreneurship education designed to raise interest in entrepreneurial activity rather than to equip students in specific skills could focus on these dimensions of entrepreneurial activity. Finally, investment in entrepreneurship education may be regarded as an instrument to address disparities in the involvement of women in entrepreneurial activity. Therefore, policies targeted towards supporting female entrepreneurship should involve an educational component. It is worth noting that for women greater exposure to entrepreneurship education leads to improvement in their self-efficacy related to marshalling and planning. Therefore, programs designed to enhance women's entrepreneurship would be more effective if they focused on these two aspects of entrepreneurial activity. 


\section{Implications for research}

This study shows that our understanding of how context affects drivers of entrepreneurial intentions is not sufficient. In particular it seems that national culture is not enough to explain the drivers of entrepreneurial intentions and entrepreneurial self-efficacy. We also need to consider other variables, such as institutional environment, including the system of entrepreneurship education. In this respect future studies should consider access to entrepreneurship-oriented courses but also access to other actions which are supportive for entrepreneurship, such as access to entrepreneurship education at secondary level, an entrepreneurship-friendly atmosphere at universities and last but not least, opportunities to be exposed to entrepreneurial role models at universities.

This paper makes a strong point that research linking entrepreneurial self-efficacy with entrepreneurial intentions would benefit from the use of more refined measures of entrepreneurial self-efficacy, such as the one developed by McGee et al. (2009). Clearly, only certain dimensions of entrepreneurial self-efficacy contribute to entrepreneurial intentions, although perhaps the other dimensions could have other positive results for students who undertake entrepreneurial activities. This is also an indication that a deeper analysis of the content of entrepreneurship courses might reveal their ultimate consequences for entrepreneurship, both in terms of encouraging entrepreneurial careers and in terms of further performance of new ventures established by graduates.

Finally, this paper raises a question of whether the pedagogical methods employed in entrepreneurship education are gender neutral. Education in Visegrad countries still relies to a considerable extent on traditional education methods, such as lectures and seminars. Simultaneously we observe that entrepreneurship education benefits female students more than men. Perhaps certain pedagogical approaches might be more appealing to women than men. Recent findings (Piperopoulos and Dimov 2015) indicate that the character of studies, 
practical or theoretical, can affect the relationship between Entrepreneurial Self-Efficacy and Entrepreneurial Intentions. Our findings suggest that it would be worthwhile to verify whether the approach to teaching entrepreneurship, theoretical versus practical, could lead to different outcomes for the entrepreneurial self-efficacy for men and women.

\section{Conclusions}

This study contributes to our understanding of the role that entrepreneurship education is playing in the development of entrepreneurial intentions. It shows that such education in the Visegrad context contributes to entrepreneurial intentions and does so mostly via its impact on entrepreneurial self-efficacy. Poland stands out as the only country in which a direct link between entrepreneurship education and entrepreneurial intentions is observed. This could be ascribed to the fact that high-school graduates in Poland enter universities in possession of some basic knowledge of entrepreneurship. An important finding of the current study is that entrepreneurial education could be helpful in increasing the entrepreneurial intentions of university graduates from Visegrad countries if it focused on the three critical dimensions of ESE: searching, marshalling and planning. While we find that female students are particularly disadvantaged as compared to men in respect to these dimensions of ESE, we find that entrepreneurship education will lessen the disparity between men and women in respect to entrepreneurial self-efficacy, and ultimately entrepreneurial intentions. Our findings highlight the positive impact of entrepreneurship education on entrepreneurial self-efficacy and entrepreneurial intentions, particularly among female students.

Finally, one needs to note that this study has some limitations which at the same time offer avenues for future research. First, it does not control for teaching methods employed in carrying out entrepreneurship education. Another limitation of the study lies in differences in sample composition between countries. While Hungarian and Polish samples consisted of 
students from different fields of study and at different levels of study (bachelor and master) the Czech sample was almost exclusively composed of business/economics students at master level. The study could benefit from using a multi-item construct of entrepreneurship education. It focuses on only two drivers of entrepreneurial intentions, of which only one can be a subject of public policy. There are other drivers of entrepreneurial intentions, such as exposure to inspiring role models, personality traits as well as public policies, including entrepreneurship friendly regulations and instruments supporting young entrepreneurs, all of which could contribute to graduate entrepreneurship. In order to align entrepreneurship education with the needs of particular student groups further studies could examine the impact of education on entrepreneurial self-efficacy in various fields of study. Last but not least, in a world which is becoming more and more global attention should be paid to intentions of international entrepreneurship and how these can be enhanced with the help of education.

\section{References}

Ahl, H. 2006. "Why research on women entrepreneurs needs new directions." Entrepreneurship theory and practice 30 (5): 595-621. doi: 10.1111/j.15406520.2006.00138.x.

Bae. T. J., Qian, S., Miao, C., and J. O. Fiet. 2014. "Entrepreneurship education and entrepreneurial intention: A meta-analytic review." Entrepreneurship Theory and Practice 38 (2): 217-254. doi: 10.1111/etap.12095.

Bandura, A. 1977. "Self-efficacy: Toward a Unifying Theory of Behavioral Change." Psychological Review 84 (2): 191-215. doi: 10.1016/0146-6402(78)90002-4.

Baumol, W. J. 1990. "Entrepreneurship: productive, unproductive, and destructive." Journal of Political Economy 98 (5): 893-921. doi: 10.1086/261712. 
Boyd, N., and G. Vozikis. 1994. "The Influence of Self-Efficacy on the Development of Entrepreneurial Intentions and Actions." Entrepreneurship Theory and Practice 18 (4): 63-77.

Carland, J. W. Carland, J. C., and M. D. Ensley. 2001. "Hunting the Heffalump: the theoretical basis and dimensionality of the Carland Entrepreneurship Index". Academy of Entrepreneurship Journal 7 (2), 51-84.

Chen C., P.G. Greene, and A. Crick. 1998. "Does entrepreneurial self-efficacy distinguish entrepreneurs from managers?" Journal of Business Venturing 13 (4): 295-316. doi: 10.1016/S0883-9026(97)00029-3.

Coviello, N.E., and M.V. Jones. 2004. "Methodological issues in international entrepreneurship research." Journal of Business Venturing 19 (4): 485-508. doi: 10.1016/j.jbusvent.2003.06.001.

Cranmer, S. 2006. "Enhancing graduate employability: best intentions and mixed outcomes." Studies in Higher Education 31 (2): 169-184. doi: 10.1080/03075070600572041.

Davey, T., Plewa, C., and M. Struwig. 2011. "Entrepreneurship perceptions and career intentions of international students." Education+ Training 53 (5): 335-352. doi: 10.1108/00400911111147677.Dempsey, D., and J. Jennings. 2014. "Gender and entrepreneurial self-efficacy: a learning perspective." International Journal of Gender and Entrepreneurship (1): 28 - 49. doi: 10.1108/IJGE-02-2013-0013.

Díaz-García, M., and F. Welter. 2011. Gender identities and practices: interpreting women entrepreneurs' narratives. International Small Business Journal 31(4): 384-404. doi: $10.1177 / 0266242611422829$. 
Drnovš̀ek, M., J. Wincent, and M. S. Cardon. 2010. "Entrepreneurial self-efficacy and business start-up: developing a multi-dimensional definition." International Journal of Entrepreneurial Behavior and Research 16 (4): 329-348. doi: $10.1108 / 13552551011054516$.

Egerová, D., Ubrežiová, I., Czeglédi, C., Nowiński, W., Čechurová, L., Eger, L., Ircingová, J., et al. 2016. Entrepreneurship education. Opportunities and challenges for Universities in Visegrad Countries, Plzen, NAVA.

Elert, N., Andersson, F. W., and K. Wennberg. 2015. "The impact of entrepreneurship education in high school on long-term entrepreneurial performance." Journal of Economic Behavior \& Organization 111: 209-223. doi: 10.1016/j.jebo.2014.12.020.

European Commision. 2006. Fostering entrepreneurial mindsets through education and learning. Brussels, 13.2.2006, $\operatorname{COM(2006)~} 33$ final. http://www.eesc.europa.eu/?i=portal.en.soc-opinions.18027.

European Commission. 2012. Effects and impact of entrepreneurship programmes in higher education, Entrepreneurship Unit Directorate-General for Enterprise and Industry .

Eurostat. 2016. Tertiary education statistics, available at: http://ec.europa.eu/eurostat/statistics-explained/index.php/Tertiary_education_statistics

Fallows, S., and Ch. Steven. 2000. "Building employability skills into the higher education curriculum: a university-wide initiative." Education + Training 42(2): 75 - 83. doi: $10.1108 / 00400910010331620$

Fayolle, A., and B. Gailly. 2008. "From craft to science, Teaching models and learning processes in entrepreneurship education." Journal of European Industrial Training 32 (2): 569-593. doi: 10.1108/03090590810899838. 
Fornell, C., and D. F. Larcker. 1981. "Evaluating structural equation models with unobservable variables and measurement error." Journal of Marketing Research 18 (3): $39-50$.

Gaweł, A., and M. Pietrzykowski 2015. "Edukacja akademicka w postrzeganiu i kształtowaniu intencji przedsiębiorczych." Problemy Zarządzania 13 (1): 41-55. doi: 10.7172/1644-9584.51.3.

Gupta, V. K., Turban, D. B., Wasti, S. A., and A. Sikdar. 2009. "The role of gender stereotypes in perceptions of entrepreneurs and intentions to become an entrepreneur." Entrepreneurship theory and practice 33 (2): 397-417. doi: 10.1111/j.1540-6520.2009.00296.x.

Hair Jr, J. F., Hult, G. T. M., Ringle, C., and M. Sarstedt. 2016. A primer on partial least squares structural equation modeling (PLS-SEM). 2ed. Sage Publications.

Henseler, J., Ringle, C.. M., and M. Sarstedt. 2015. "A new criterion for assessing discriminant validity in variance-based structural equation modeling." Journal of the Academy of Marketing Science 43 (1): 115-135, doi:10.1007/s11747-014-0403-8.

Henseler, J., Ringle, C. M., and M. Sarstedt. 2016. "Testing measurement invariance of composites using partial least squares." International Marketing Review 33(3): 405-431. doi:10.1108/IMR-09-2014-0304

Henseler, J., Ringle, C. M., and R. R. Sinkovics. 2009. "The use of partial least squares path modeling in international marketing." In New challenges to international marketing (Advances in International Marketing, Volume 20), edited by R. R. Sinkovics, P. N. Ghauri, 277-319. Emerald Group Publishing Limited.

Huber, L. R., Sloof, R., and M. Van Praag. 2014. "The effect of early entrepreneurship education: Evidence from a field experiment." European Economic Review, 72, 76-97. doi: 10.1016/j.euroecorev.2014.09.002. 
https://geert-hofstede.com/ accessed as of 22 July 2017

Jensen, S. M., and F. Luthans. 2006. "Entrepreneurs as authentic leaders: Impact on employees' attitudes." Leadership \& Organization Development Journal 27 (8): 646666. doi: 10.1108/01437730610709273.

Kautonen, T., Gelderen, M., and M. Fink. 2015. "Robustness of the theory of planned behavior in predicting entrepreneurial intentions and actions." Entrepreneurship Theory and Practice 39 (3): 655-674. doi: 10.1111/etap.12056.

Kelley, D. J., Brush, C. G., Greene, P. G., and Y. Litovsky. 2012. Global Entrepreneurship Monitor Women's Report, Global Entrepreneurship Research Association.

Kemelgor, B. H. 2002. "A comparative analysis of corporate entrepreneurial orientation between selected firms in the Netherlands and the USA." Entrepreneurship \& Regional Development 14 (1): 67-87. doi: 10.1080/08985620110087023.

Krueger, Jr N. F., and D. V. Brazeal. 1994. "Entrepreneurial Potential and Potential Entrepreneurs." Entrepreneurship: Theory \& Practice 18 (3): 91-104.

Krueger, Jr N. F., and M. D. Reilly. 2000. "Competing models of entrepreneurial intentions." Journal of Business Venturing 15(5/6): 411-432. doi: 10.1016/S0883-9026(98)00033-0.

Kurczewska, A., and J. Białek. 2014. "Is the interplay between self-efficacy and entrepreneurial intention gender specific?" Argumenta Oeconomica 33 (2): 23-38. doi: 10.15611/aoe.2014.2.02.

Liñán, F., and Y. W. Chen 2009. "Development and Cross-Cultural Application of a Specific Instrument to Measure Entrepreneurial Intentions." Entrepreneurship Theory and Practice 33 (3): 593-617. doi: 10.1111/j.1540-6520.2009.00318.x.

Lings, I., Durden, G., Lee, N., and J. W. Cadogan 2014. "Socio-Emotional and Operational Demands On Service Employees." Journal of Business Research 67(10): 2132-2138. doi: 10.1016/j.jbusres.2014.04.022. 
Lockwood, F., Teasley, R., Carland, J. A. C., and J. W. Carland. 2006. "An examination of the power of the dark side of entrepreneurship." International Journal of Family Business, 3, 1-20.

Louw, L., Van Eeden, S. M., Bosch, J. K., and D. J. L. Venter. 2003. "Entrepreneurial traits of undergraduate students at selected South African tertiary institutions." International Journal of Entrepreneurial Behavior \& Research 9 (1): 5-26. doi: $10.1108 / 13552550310461027$.

Lowry, P. B., and J. Gaskin. 2014. "Partial Least Squares (PLS) Structural Equation Modeling (SEM) for Building and Testing Behavioral Causal Theory: When to Choose It and How to Use It." IEEE TPC 57 (2): 123-146. doi: 10.1109/TPC.2014.2312452.

Lüthje, C. and N. Franke. 2003. "The making of an entrepreneur: testing a model of entrepreneurial intent among engineering students at MIT." $R \& D$ Management 33 (2): 135-147. doi: 10.1111/1467-9310.00288.

Maresh, D., Harms, R., Kailer, N., and B. Wimmer-Wurm. 2016. "The impact of entrepreneurship education on the entrepreneurial intention of students in science and engineering versus business studies university programs." Technological Forecasting and Social Change 104: 172-179. doi: 10.1016/j.techfore.2015.11.006.

Martin, B. C., McNally, J. J., and M. J. Kay. 2013. "Examining the formation of human capital in entrepreneurship: A meta-analysis of entrepreneurship education outcomes," Journal of Business Venturing 28 (2): 211-224. doi: 10.1016/j.jbusvent.2012.03.002.

McGee, J. E., Peterson, M., Mueller, S. L., and J. M. Sequeira. 2009. "Entrepreneurial SelfEfficacy: Refining the Measure." Entrepreneurship Theory and Practice 33 (4): 965988. doi: 10.1111/j.1540-6520.2009.00304.x. 
Mitchelmore, S., and J. Rowley. 2013. "Entrepreneurial competencies of women entrepreneurs pursuing business growth." Journal of Small Business and Enterprise Development, 20 (1): 125-142. doi: 10.1108/14626001311298448.

Mwasalwiba, E. S. 2010. "Entrepreneurship education: a review of its objectives, teaching methods, and impact indicators." Education + Training 52 (1): 20-47. doi: $10.1108 / 00400911011017663$

Oosterbeek, H., van Praag, M., and A. Ijsselstein 2010. "The impact of entrepreneurship education on entrepreneurship skills and motivation." European Economic Review 54 (3): 442-454. doi: 10.1016/j.euroecorev.2009.08.002.

Packham, G., Jones, P., Miller, C., Pickernell, D., and T. Brychan. 2010. "Attitudes towards entrepreneurship education: a comparative analysis." Education+ Training 52 (8/9): 568-586. doi: 10.1108/00400911011088926.

Piperopoulos, P., and D. Dimov. 2015. "Burst Bubbles or Build Steam? Entrepreneurship Education, Entrepreneurial Self-Efficacy, and Entrepreneurial Intentions." Journal of Small Business Management 53 (4): 970-985. doi: 10.1111/jsbm.12116.

Pittaway, L., and J. Cope. 2007. "Entrepreneurship Education:- A Systematic Review of the Evidence." International Small Business Journal 25 (5): 479-510. doi: $10.1177 / 0266242607080656$.

Podsakoff, P. M., MacKenzie, S. B., Lee J-Y and N. P. Podsakoff. 2003. "Common method biases in behavioral research: A critical review of the literature and recommended remedies." Journal of Applied Psychology 88 (5): 879-903. doi: 10.1037/00219010.88 .5 .879

Preston, J. and A. Green. 2003, "The macro-social, training and skills in comparative perspective", Report No. 9, Centre for Research on the Wider Benefits of Learning, London. 
Ringle, C. M., Wende, S., and J. M. Becker. 2015. SmartPLS 3. Boenningstedt: SmartPLS GmbH, http://www.smartpls.com.

Sanchez, J. C. 2013. "The impact of entrepreneurship education program on entrepreneurial competencies and intention." Journal of Small Business Management 51(3): 447-465. doi: $10.1111 /$ jsbm. 12025

Santos, F. J., Roomi, M.A., and F. Liñán. 2016. "About Gender Differences and the Social Environment in the Development of Entrepreneurial Intentions." Journal of Small Business Management 54(1): 49-66. doi: 10.1111/jsbm.12129

Schlägel, C., and M. Sarstedt. 2016. "Assessing the measurement invariance of the fourdimensional cultural intelligence scale across countries: A composite model approach." European Management Journal 34(6): $\quad$ 633-649. https://doi.org/10.1016/j.emj.2016.06.002

Severiens, S. E., and G. T. M. ten Dam. 1994." Gender differences in learning styles: A narrative review and a quantitative meta-analysis." Higher Education 27(4): 487-501. doi: 10.1007/BF01384906

Shinnar R., Hsu, D. K., and B. C. Powell. 2014. "Self-efficacy, entrepreneurial intentions, and gender: Assessing the impact of entrepreneurship education longitudinally." International Journal of Management Education $12 \quad$ (3): 561-570. https://doi.org/10.1016/j.ijme.2014.09.005.

Shneor, R., Camgöz, S. M., and P. B. Karapinar. 2013. "The interaction between culture and sex in the formation of entrepreneurial intentions." Entrepreneurship \& Regional Development 25 (9-10): 781-803. doi: 10.1080/08985626.2013.862973.

Sin, C., and G. Neave. 2016. "Employability deconstructed: perceptions of Bologna stakeholders." Studies In Higher Education 41 (8): 1447-1462. doi: $10.1080 / 03075079.2014 .977859$. 
Souitaris, V., Zerbinati, S., and A. Al-Laham. 2007. "Do entrepreneurship programmes raise entrepreneurial intention of science and engineering students? The effect of learning, inspiration and resources." Journal of Business Venturing 22 (4): 566-591. doi: 10.1016/j.jbusvent.2006.05.002.

Stamboulis, Y., and A. Barlas. 2014. "Entrepreneurship education impact on student attitudes." The International Journal of Management Education 12 (3): 365-373. doi: 10.1016/j.ijme.2014.07.001.

Thébaud, S. 2010. "Gender and Entrepreneurship as a Career Choice: Do Self-assessments of Ability Matter?" Social Psychology Quarterly 73 (3): 288-304. doi: $10.1177 / 0190272510377882$.

Thompson, E. R. 2009. "Individual entrepreneurial intent: Construct clarification and development of an internationally reliable metric." Entrepreneurship Theory and Practice, 33 (3): 669-694. doi: 10.1111/j.1540-6520.2009.00321.x.

Van der Zwan, P., Zuurhout, P., and J. Hessels. 2013. "Entrepreneurship education and self employment: The role of perceived barriers." Zoetermeer, January 2013, EIM Research Reports, available online at: http://ondernemerschap.panteia.nl/pdf-ez/h201301.pdf

Van Praag, C. M., and P. H. Versloot. 2007. "What is the value of entrepreneurship? A review of recent research." Small Business Economics, 29 (4): 351-382. doi:10.1007/s11187007-9074-x.

Walter, S. G., and J. H. Block. 2016. "Outcomes of entrepreneurship education: An institutional perspective." Journal of Business Venturing 31 (2): 216-233. doi: 10.1016/j.jbusvent.2015.10.003.

Wehrwein, E. A., Lujan, H. L., and S. E. DiCarlo. 2007. "Gender differences in learning style preferences among undergraduate physiology students." Advances in Physiology Education 31 (2): 153-157. doi: 10.1152/advan.00060.2006. 
Westhead, P., and M. Z. Solesvik. 2016. "Entrepreneurship education and entrepreneurial intention: Do female students benefit?" International Small Business Journal 34 (8): 979-1003. doi: 10.1177/0266242615612534.

Wilson, F., Kickul, J., and D. Marlino. 2007. "Gender, Entrepreneurial Self-Efficacy, and Entrepreneurial Career Intentions: Implications for Entrepreneurship Education." Entrepreneurship: Theory \& Practice 31 (3): 387-406. doi: 10.1111/j.15406520.2007.00179.x.

Wilson, F., Kickul, J., Marlino, D., Barbosa, S. D., and M. D. Griffiths. 2009. "An analysis of the role of gender and self-efficacy in developing female entrepreneurial interest and behavior." Journal of Developmental Entrepreneurship 14 (2): 105-119. doi: 10.1142/S1084946709001247.

Wu, L. Y. 2007. "Entrepreneurial resources, dynamic capabilities and start-up performance of Taiwan's high-tech firms." Journal of Business Research 60 (5): 549-555. doi: 10.1016/j.jbusres.2007.01.007.

Zhang. Y., Duysters, G., and M. Cloodt. 2014 "The role of entrepreneurship education as a predictor of university students' entrepreneurial intention." International Entrepreneurship and Management Journal 10 (3): 623-641. doi:10.1007/s11365-0120246-z.

Zhao, H., Seibert, S.E., and G.E. Hills. 2005. "The mediating role of self-efficacy in the development of entrepreneurial intentions." Journal of Applied Psychology 90 (6): 1265-1272. doi: 10.1037/0021-9010.90.6.1265. 